\title{
Superparamagnetic iron oxide nanoparticles functionalized with peptides by electrostatic interactions
}

\author{
Nicole Hildebrandt, ${ }^{a}$ Dana Hermsdorf, ${ }^{b}$ Ruth Signorell, ${ }^{b}$ Stephan A. Schmitz, ${ }^{c}$ and \\ Ulf Diederichsen $^{\mathrm{a}, *}$ \\ ${ }^{a}$ Institut für Organische und Biomolekulare Chemie, Georg-August-Universität Göttingen, \\ Tammannstr. 2, 37077 Göttingen, Germany \\ ${ }^{b}$ Department of Chemistry, University of British Columbia, 2036 Main Mall, Vancouver, B. C., \\ V6T 1Z1, Canada \\ ${ }^{c}$ Hammersmith Hospital, Faculty of Medicine, Imperial College, Du Cane Rd, London, W12 \\ OHS, UK \\ E-mail: udieder@gwdg.de
}

Dedicated to Prof. Dr. Dr. h.c. Lutz F. Tietze on the occasion of his $65^{\text {th }}$ birthday

\begin{abstract}
Superparamagnetic iron oxide nanoparticles coated with dextran were functionalized with negatively charged functionalities in order to connect specific peptide labels by electrostatic interactions. Peptide binding on the nanoparticles was indicated by HR-TEM, an electrospray scanning mobility particle sizer, and fluorescence measurements.
\end{abstract}

Keywords: Electron microscopy, molecular recognition, nanoparticles, peptides, self-assembly

\section{Introduction}

Contrast agents provide an established tool in clinical magnetic resonance imaging (MRI). All contrast agents induce a decrease in the $T_{1}$ and $T_{2}$ relaxation times of surrounding water protons and thereby manipulate the signal intensity of the imaged tissue. ${ }^{1}$ While traditional contrast agents distribute rather non-specifically, molecular imaging probes have been developed that specifically label body tissue or cells. ${ }^{2}$ Furthermore, visualizing a single property of a pathological entity with one agent is generally insufficient to characterize it accurately in clinical MRI. Therefore, we aim at developing an imaging probe that permits study of several aspects of a pathological entity with only one intravenous injection. With respect to our interest in atherosclerosis, an angiogram would show the arteries. A specific ligand would bind the probe acute arterial thrombus which carries a high risk for stroke and heart attack. A second ligand 
would mediate transendothelial transport and indicate macrophage accumulation in inflammatory atherosclerotic wall plaque. Although preliminary studies have shown the potential of the appropriate MRI techniques to readily identify and differentiate these three characteristics, previous superparamagnetic iron-oxide nanoparticles (SPIO's) as diagnostic agents had insufficient unspecific binding for acute thrombus and some limited uptake in macrophage cells of inflammatory atherosclerotic plaque.,

SPIO's are small superparamagnetic iron-oxide nanoparticles with a crystalline magnetite structure coated with dextran or dextran derivatives. ${ }^{5}$ They are a promising group of imaging probes since MR signal intensity is manipulated, they have a favorable toxicity, and genuine potential for cellular uptake. Furthermore, SPIO's are incorporated by several phagocytic cells, in particular macrophages in liver and spleen even with a regular dextran coat. ${ }^{1}$ Modification of the dextran coating by carboxylation leads to a shorter clearance half-life in blood. ${ }^{6,7}$ Ferumoxytol, a carboxyalkylated polysaccharide coating, ${ }^{8}$ is already described as a good first-pass contrast agent, ${ }^{9}$ but uptake by macrophages is unspecific and too fast to enhance the uptake in macrophage-rich plaques. In order to improve the cell uptake in general, Weissleder et al. combined the tat peptide from the HIV tat protein with particles (CLIO, cross-linked iron oxide) covalently linked by a thioether. ${ }^{10}$ This leads to an increase of particle incorporation into spleen and liver. However, they are enriched close to the nucleus, indicating a different uptake mechanism caused by the peptide. Therefore, it is our intention to use specific peptide labels to address the particles towards relevant targets in blood vessels. ${ }^{11}$ For example, the peptide with the sequence IELLQAR is known for selective binding to the E-selectin receptor on injured artery walls. ${ }^{12}$ Cell uptake and specific direction of particles might be obtained by small particles labeled with the respective peptide sequence.

The attachment of peptide oligomers to the dextran-coated iron oxide particles was addressed by electrostatic interactions as a general non-specific and efficient method for recognition. This way of labeling is independent of the specific recognition sequence. Similarly, electrostatic interactions are used already for the deposition of polysaccharide multilayers on damaged arteries by an alternating aggregation of polycationic chitosan and polyanionic hyaluronan. ${ }^{13}$ Also, dextran sulfate can be used to form layer-by-layer assemblies with proteins based on charge-charge interactions. ${ }^{14}$ SPIO's modified by electrostatic interactions with transition agents such as poly-lysine are used for magnetic labeling of mammalian cells. ${ }^{15}$ In this case, the negative charges on the particle surface resulting from its preparation seem sufficient to bind the large polycation.

Within this study, small peptides were bound to SPIO's using electrostatic interactions. Peptides containing a specific recognition sequence and amino acids that are positively charged under physiological conditions were bound to the negatively charged surface of a modified dextran. It needed to be proved that iron oxide particles are still stabilized by polysaccharide coating even the dextran derivative contains negative charges. Furthermore, the influence of functionalization by charge-charge interactions on the particle stability and the amount of charges required for attachment of the peptide label was investigated. Superparamagnetic 
particles were provided that, in principle, can be combined with any peptide carrying a recognition sequence shortly before injection. In particular, SPIO's labeled with a set of different peptides with individual targeting might be of interest in the future. The binding was estimated by size distribution and fluorescence measurements. In comparison with TEM measurements, the electrospray scanning mobility particle sizer (ES-SMPS) was introduced for the first time to analyze charged particles.

\section{Results and Discussion}

As the first example, the peptide sequence IELLQAR was chosen as the recognition motif known for inhibition of sialyl Lewis $\mathrm{X}$ binding to the E-selectin receptor. ${ }^{12}$ For electrostatic labeling of the nanoparticles three or six lysine amino acids, respectively, were added to the $C$ terminal end. At the $\mathrm{N}$-terminus a dansyl group was connected as the fluorescent dye allowing for later detection of the particle-bound peptides. The dansyl group is stable under peptidecleavage conditions and the UV absorption of the particle $\left(\lambda_{\text {abs.max }}=270 \mathrm{~nm}\right)$ does not affect its excitation $\left(\lambda_{\text {exc }}=325 \mathrm{~nm}\right)$ or fluorescence $\left(\lambda_{\text {fl.max }}=525 \mathrm{~nm}\right)$. Synthesis of the peptides was provided by standard automated Fmoc solid phase peptide synthesis protocols on a Wang resin. ${ }^{16}$ The dansyl group was introduced by addition of dansyl chloride and triethylamine in methylene chloride to the resin-bound oligomer. ${ }^{17}$ After cleavage from the solid support the two oligomers, dansyl-IELLQARKKK-OH (1) and dansyl-IELLQARKKKKKK-OH (2), were obtained, ${ }^{18}$ differing in the amount of lysine residues for electrostatic interaction with the modified dextran coating of the particles.

In order to generate iron oxide nanoparticles with negatively charged surfaces we decided on a dextran-methylcarboxylate coating 3 as indicated in Scheme 1 . Dextran $\left(M_{\mathrm{w}}=40000 \mathrm{~g} \mathrm{~mol}^{-1}\right)$ was modified with monochloracetic acid according to a known protocol. ${ }^{18}$ The carboxyl groups were introduced without any regiocontrol providing $4.6 \mathrm{mmol} \mathrm{COO}^{-} \mathrm{g}^{-1}$ as determined by titration with $0.1 \mathrm{M} \mathrm{HCl}$. Whereas formation of dextran-methylcarboxylate iron oxide nanoparticles (4) by modification of the dextran- coated SPIO's was not successful, the respective particles have been obtained by iron oxide coating with the carboxylated dextran. In analogy to the dextran coated SPIO's, dextran-methylcarboxylate (3) was transformed with $\mathrm{FeCl}_{2}, \mathrm{FeCl}_{3}$ and ammonium hydroxide at $80{ }^{\circ} \mathrm{C}$ for $2 \mathrm{~h} .{ }^{19}$ The amount of carboxyl groups was proved to be unchanged after particle formation. 


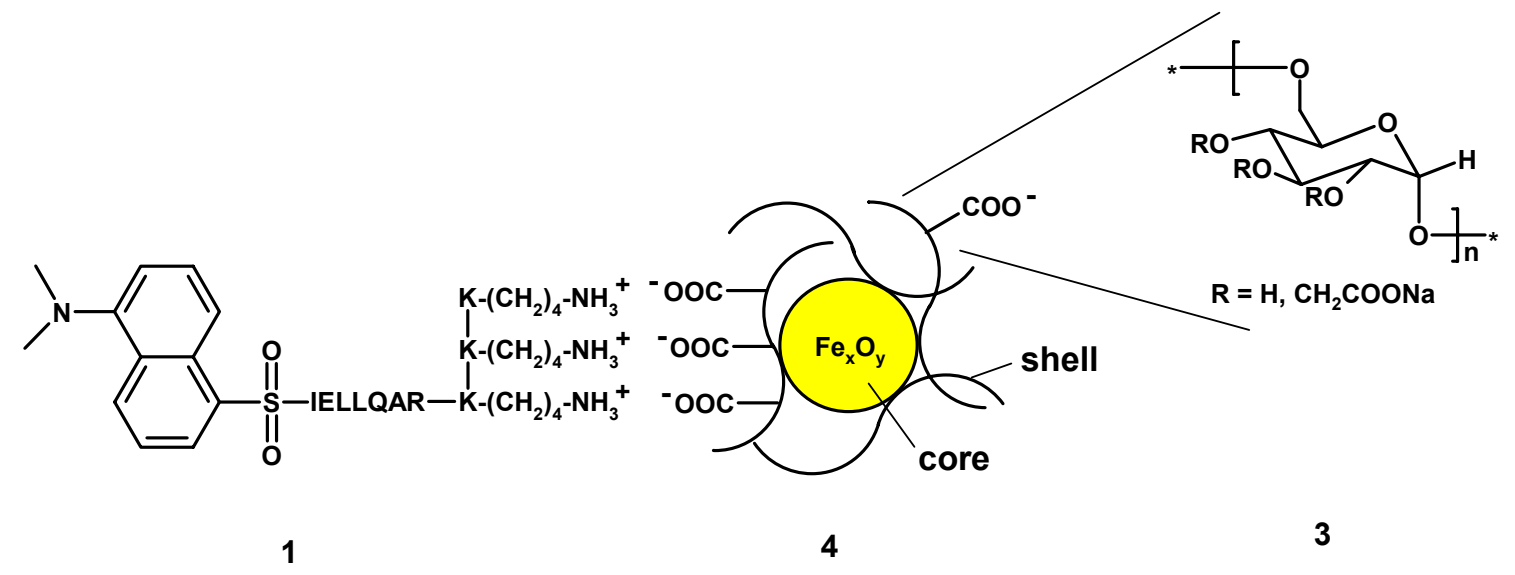

Scheme 1. Coated (dextran-methylcarboxylate, 3) superparamagnetic iron oxide particle 4 electrostatically connected to the peptide 1 .

The size of the dextran-methylcarboxylate particles 4 was investigated by HR-TEM (high resolution transmission electron microscopy) resulting in a size distribution around $20 \mathrm{~nm}$ (Figures 1 and 2). The accuracy of the TEM measurements was estimated to be higher than 95\%.

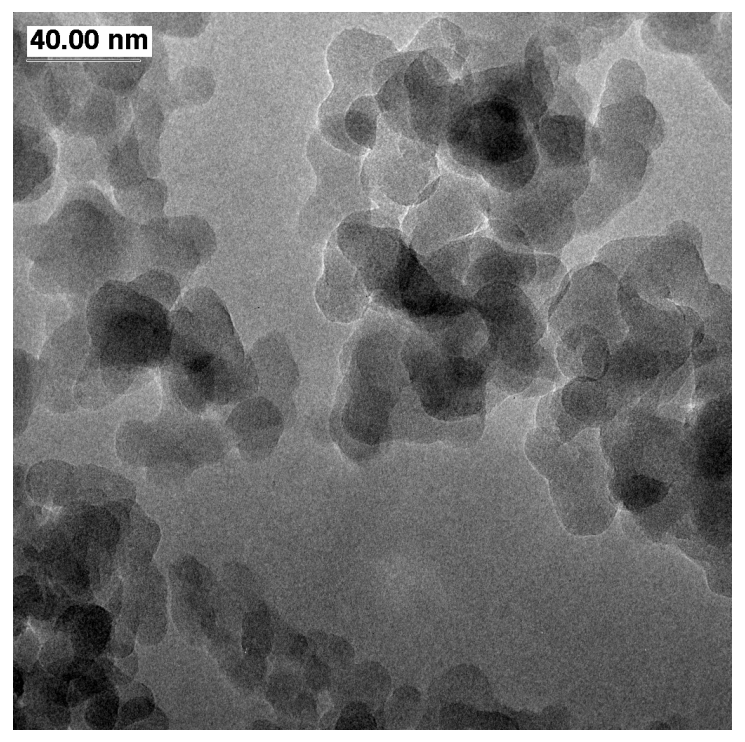

Figure 1. HR-TEM (CM 200 FEG-UT) of particle 4. One drop of a $0.3 \mathrm{nmol} / \mathrm{mL}$ solution of 4 was added on a copper grid with a lacey-carbon film and air-dried. The size is indicated by the bar). 


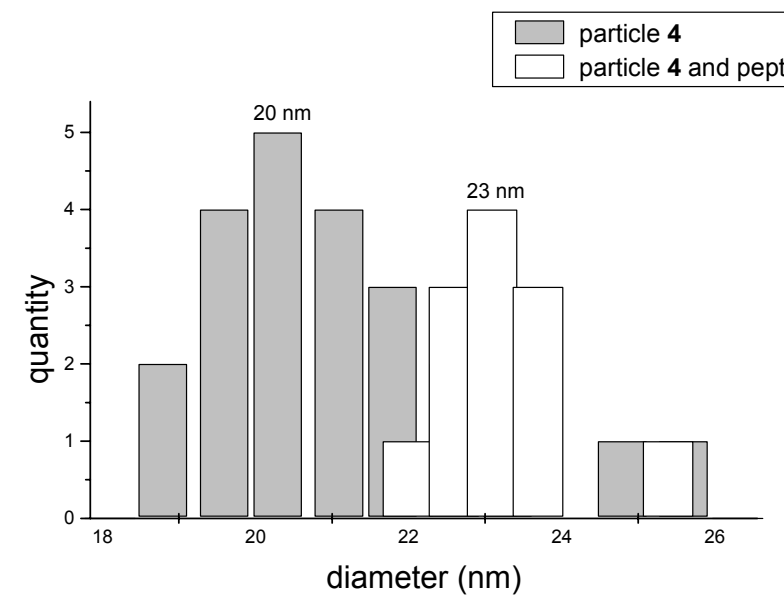

Figure 2. Size-distribution of nanoparticle 4 and nanoparticle 4 + peptide 1 measured by HRTEM.

As a second method for size-determination of the nanoparticles, electrospray (ES) was used in combination with a scanning mobility particle sizer (SMPS) ${ }^{20}$ The solution containing nanoparticles was sprayed in the ES with subsequent solvent evaporation. The size-distribution of the generated aerosol was determined with the SMPS, resulting in a distribution of particles 4 around $8.4 \mathrm{~nm}$ assuming singly charged particles (Figure 3 ).

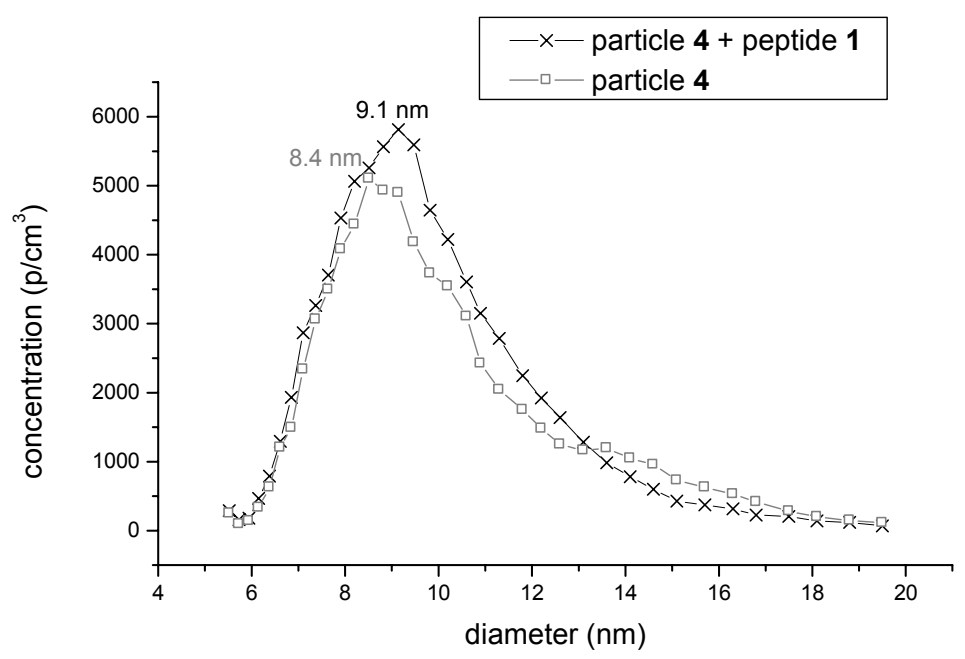

Figure 3. Size distribution of nanoparticle 4 and nanoparticle $4+$ peptide 1 measured by ESSMPS assuming singly charged particles. For doubly charged particles sizes of $16.8 \mathrm{~nm}$ and 18.2 $\mathrm{nm}$, respectively, would result. 
Both methods clearly indicate the successful formation of particles. Nevertheless, the differing results obtained for the diameters of the particles are probably due to a higher population of doubly-charged particles in the ES-SMPS measurements; this would imply an increase of the real particle size by a factor of two. In addition, the particle size in the TEM measurements is usually overestimated with respect to ES, since higher concentrations are required for TEM solutions resulting in correspondingly larger amounts of impurities from the synthesis which might cover the nanoparticles after drying. Overall, the results obtained by ESSMPS and TEM seem to agree reasonably well, considering the two points mentioned.

For the attachment of the respective peptides $\mathbf{1}$ or $\mathbf{2}$ to particle $\mathbf{4}$ an aqueous solution of the components was kept overnight at room temperature to guarantee an electrostatic equilibrium. HR-TEM and ES-SMPS experiments were performed for the functionalization of the particles with peptide $1 .{ }^{20}$ The particle diameter increased significantly by about $15 \%$ from $20 \mathrm{~nm}$ to 23 $\mathrm{nm}$ as indicated by HR-TEM measurements (Figure 2). Also by ES-SMPS an increase of particle size from $8.4 \mathrm{~nm}$ to $9.1 \mathrm{~nm}$ was detected (assuming singly charged particles) (Figure 3). Both methods indicate an enlargement of the particle size, probably owing to loading of the negatively charged surface of the dextran-methylcarboxylate coated particles with peptides. The attachment of peptides by electrostatic interactions seems to be quite stable under aqueous conditions at neutral $\mathrm{pH}$.

Further proof for particle functionalization was obtained by fluorescence measurements' detecting the dansyl labeling of the particle-bound peptides. In addition, this method allows estimation of the influence of the amount of positive charged amino acids on the stability of complex formation. Particle-peptide combinations $\mathbf{4}+\mathbf{1}$ and $\mathbf{4}+\mathbf{2}$ were independently separated from all unbound peptides using an ultrafiltration device with a molecular-weight cut of $5000 \mathrm{D}$ in combination with centrifugation. After thoroughly washing with water, the fluorescence was determined (Table 1). 
Table 1. Ratio of peptide/amount of carboxylic acid groups calculated according to fluorescence experiments $^{\mathrm{a}}$

\begin{tabular}{lcc}
\hline & Twice distilled water $^{\mathrm{b}}$ & $0.1 \mathrm{MNaCl}^{\mathrm{c}}$ \\
\hline Complex of particle $\mathbf{4}$ and peptide $\mathbf{1}$ & $1: 2.7$ & no fluorescence \\
Complex of particle $\mathbf{4}$ and peptide $\mathbf{2}$ & $1: 4.8$ & $1: 9.8$ \\
\hline
\end{tabular}

${ }^{\mathrm{a}}$ Fluorescence experiments were performed in twice-distilled water, $\lambda_{\mathrm{exc}}=325 \mathrm{~nm}, \lambda_{\mathrm{em}}=$ 400-600 nm. Calibration curves with known concentrations were measured for peptide $\mathbf{1}$ and $\mathbf{2}$, respectively. ${ }^{\mathrm{b}}$ Measurements were performed after washing with water using an ultrafiltration device. ${ }^{\mathrm{c}}$ Measurements were performed after washing with $0.1 \mathrm{M} \mathrm{NaCl}$ using an ultrafiltration device.

In both of the cases above, the peptide seems to be well bound to the particle; peptide $\mathbf{1}$ with three lysines required 2.7 carboxylic acid groups for binding whereas peptide 2 with six lysine residues was already bound by 4.8 carboxylic acid residues. In order to estimate the stability of the electrostatic interaction, both samples were washed with a $0.1 M \mathrm{NaCl}$ solution using the ultrafiltration device. Peptide 1 was completely cleaved from the particle, since no fluorescence was detectable any more, whereas about half of the peptide loading was still present for the case of peptide $\mathbf{2}$. Therefore, six lysine residues provide significantly more stability than three lysines. Further improvement of the binding stability might be obtained by linear or dendrimer-like extension of the lysine sequence.

In order to estimate the need for the dextran coat functionalization with negative charges for binding peptides, a particle covered with regular dextran was synthesized. ${ }^{19}$ It was incubated with peptide 1 and separated from all unbound peptides using the ultrafiltration device in combination with centrifugation. After thoroughly washing with water no fluorescence was determined, indicating that negative charges resulting from the particle preparation are not sufficient to bind peptides with three positive charges by electrostatic interaction, even though this effect was reported for poly-lysine. ${ }^{15}$

A tag with the length of about six positively charged amino acids seemed to be sufficient to address dextran-coated iron oxide nanoparticles. Therefore, we introduced a general method of selectively functionalizing these kinds of particles with specific-recognition- as well as celltransport units. Before targeting selective binding sites in vitro and in vivo, further stability tests under protein- containing conditions are planned to ensure that the peptide stays associated in human blood. 


\section{Experimental Section}

General Procedures. ${ }^{1} \mathrm{H}$ - NMR spectra were obtained on a Varian U 300 at $300 \mathrm{MHz}$, with chemical shifts being reported as ppm from trimethylsilane as internal standard. IR spectra were recorded on a Perkin Elmer FTIR 1600. Analytical and preparative HPLC were performed on an Amersham Pharmacia Biotech P 900. The mass spectra were measured on a Finnigan LQC spectrometer. For the concentration and cleaning of particle solutions, a Vivaspin $6 \mathrm{ml}$ concentrator (MWCO 5000, PET membrane) was used as ultrafiltration device. Millipore $\mathrm{H}_{2} \mathrm{O}$ was employed for the preparation of all aqueous solutions.

High resolution transmission electron microscopy (HR-TEM) measurements were carried out using a CM 200 FEG-UT. To prepare the samples, a drop of a solution containing the desired dextran-methylcarboxylate particle (4) $\left(\mathrm{c}=c a .0 .3 \mathrm{nmol} \mathrm{mL} \mathrm{mL}^{-1}\right.$, assuming that the average molecular weight of particle 4 is $60,000 \mathrm{~g} \mathrm{~mol}^{-1}$ ) was dried on a carbon- layered copper grid (Formvar/carbon film, $400 \mathrm{mesh}, \mathrm{d}=3.05 \mathrm{~mm}$ ).

For ES-SMPS (electrospray-scanning mobility particle sizer) measurements, particle solutions with different concentrations were sprayed in the ES (TSI 3480) at $2.0 \mathrm{kV}$ and examined by the SMPS equipped with a differential mobility analyzer for small particles (TSI 3936N25). The particle concentration of the sample was decreased until the maximum diameter measured was constant. The best results were examined at a dextran-methylcarboxylate particle concentration of $c a .75 \mathrm{pmol} \mathrm{mL}^{-1}$ (assuming that the average molecular weight of particle 4 is $60,000 \mathrm{~g} \mathrm{~mol}^{-1}$ ). Fluorescence experiments were recorded on a Jasco FP-6200 spectrometer. The samples were dissolved in $\mathrm{H}_{2} \mathrm{O}$. With excitation at $\lambda_{\text {exc }}=325 \mathrm{~nm}$ fluorescence was measured at $\lambda_{\mathrm{em}}=400-600 \mathrm{~nm}$. The peptide concentration of the sample was linked to the peak-area by a linear relationship. For each sample the concentration was adjusted to an UV absorbance of 0.1 $\left(\lambda_{\text {abs. }}=325 \mathrm{~nm}\right)$. Afterwards, the concentration was continuously enhanced.

\section{Compound characterization}

Dansyl-IELQARKKK-OH (1) and dansyl-IELQARKKKKKK-OH (2). After standard automated Fmoc solid-phase peptide synthesis of the respective peptides on Wang resin (150 mg, $100 \mu \mathrm{mol}, 1$ eq.), the dry resin was swelled in $\mathrm{CH}_{2} \mathrm{Cl}_{2}(4 \mathrm{~mL})$ for $1 \mathrm{~h}$. A solution of dansyl chloride (110 mg, $400 \mu \mathrm{mol}, 4$ eq.) and triethylamine $(125 \mu \mathrm{L})$ in $\mathrm{CH}_{2} \mathrm{Cl}_{2}(6 \mathrm{~mL})$ was added to the resin $\left(100 \mu \mathrm{mol}, 1\right.$ eq.) and shaken for $2 \mathrm{~h}$ at RT. The resin was washed with $\mathrm{CH}_{2} \mathrm{Cl}_{2}$ $(5 \times 4 \mathrm{~mL})$ until the yellow color of the dansyl chloride disappeared. After drying in vacuum, the peptide was cleaved from the resin by a mixture of TFA-triisopropylsilane-anisole-1,4dithiothreitol $-\mathrm{H}_{2} \mathrm{O}=46 / 1 / 1 / 1 / 1(\mathrm{v} / \mathrm{v} / \mathrm{v} / \mathrm{w} / \mathrm{v})$ during $2 \mathrm{~h}$ at $\mathrm{RT}$. The peptides were precipitated in cold diethyl ether. HPLC-purification $\left(\mathrm{CH}_{3} \mathrm{CN} / \mathrm{H}_{2} \mathrm{O} / \mathrm{TFA} ; \mathrm{YMC}\right.$ J'sphere ODS-H80 $250 \times 4.6 \mathrm{~mm})$ provided the desired peptides $1(13 \mathrm{mg}, 9.1 \mu \mathrm{mol}, 9 \%)$ and $2(5.3 \mathrm{mg}, 2.8 \mu \mathrm{mol}$, $3 \%$ ), respectively. Peptide 1: ESI-MS $m / z$ (rel. \%): $487(23)[\mathrm{M}+3 \mathrm{H}]^{3+}, 730(82)[\mathrm{M}+2 \mathrm{H}]^{2+}$, 1460 (100) $[\mathrm{M}+\mathrm{H}]^{+}$. Peptide 2: ESI-MS $m / z$ (rel. \%): 615 (59) $[\mathrm{M}+3 \mathrm{H}]^{3+}, 922$ (12) $[\mathrm{M}+2 \mathrm{H}]^{2+}$. 
For fluorescence experiments, calibration curves for the peptides $\mathbf{1}$ and $\mathbf{2}$ were needed. Therefore, peptide $1(0.90 \mathrm{mg}, 0.62 \mu \mathrm{mol})$ and peptide $2(1.2 \mathrm{mg}, 0.66 \mu \mathrm{mol})$, respectively, were dissolved in $\mathrm{H}_{2} \mathrm{O}(1 \mathrm{~mL})$. Known amounts of these solutions were added to a cuvette containing $\mathrm{H}_{2} \mathrm{O}(1.2 \mathrm{~mL})$, fluorescence spectra were measured, and the peak areas $\lambda_{\mathrm{em}}=400-600 \mathrm{~nm}$ determined. A linear fit of the calibration curves yielded the following relationship between peak area (a) and peptide concentration (c): peptide 1: $\mathrm{a}=1629 \mathrm{c}-86$; peptide 2: $\mathrm{a}=1881 \mathrm{c}-451$.

Dextran methylcarboxylate (3). Dextran $\left(\mathrm{M} \sim 40,000 \mathrm{~g} \mathrm{~mol}^{-1} ; 1 \mathrm{~g}\right)$ and $\mathrm{NaOH}(1.2 \mathrm{~g})$ were suspended in isopropanol $/ \mathrm{H}_{2} \mathrm{O}(85 / 15 ; 22 \mathrm{~mL})$ and heated to $60^{\circ} \mathrm{C}$. Monochloracetic acid $(1.5 \mathrm{~g})$ was added slowly and the mixture was stirred for $2 \mathrm{~h}$ at $60^{\circ} \mathrm{C}$. After cooling to $\mathrm{RT}$, the organic solvent was removed under reduced pressure and the aqueous phase was neutralized with acetic acid. Cold $\mathrm{MeOH}(30 \mathrm{~mL})$ was added and the solution was kept at $4{ }^{\circ} \mathrm{C}$ overnight. After drying of the precipitate at high vacuum dextran-methylcarboxylate (3) (1.5 g) was obtained. Titration of dextran-methylcarboxylate (3) $(57 \mathrm{mg})$ with $0.1 \mathrm{M} \mathrm{HCl}(2.6 \mathrm{~mL}, 0.26 \mathrm{mmol})$ and bromphenol blue in acetone $/ \mathrm{H}_{2} \mathrm{O}(1 / 1,10 \mathrm{~mL})$ resulted in $4.6 \mathrm{mmol} \mathrm{COO} \mathrm{g}^{-1}$. Therefore, on average, $74 \%$ of all glucose units were modified with monochloracetic acid. Decomp. $240{ }^{\circ} \mathrm{C}$; ${ }^{1} \mathrm{H}$ NMR $\left(300 \mathrm{MHz}, 25{ }^{\circ} \mathrm{C}, \mathrm{D}_{2} \mathrm{O}\right): \delta=3.42-3.98(\mathrm{~m}, 3 \mathrm{H}, 3-\mathrm{H}, 4-\mathrm{H}, 5-\mathrm{H}), 4.00\left(\mathrm{~d},{ }^{3} J_{(H, H)}=2 \mathrm{~Hz}\right.$, $2 \mathrm{H}, \mathrm{CH}_{2}-\mathrm{COONa}$ ), 4.01-4.40 (m, 3H, 2-H, 6- $\left.\mathrm{H}_{2}\right), 4.98-5.28$ (m, 1H, 1-H) ppm; IR (KBr): $v=3433(\mathrm{OH}), 1604(\mathrm{C}=\mathrm{O}), 1419,1326,1103,1010(\mathrm{C}-\mathrm{O}-\mathrm{C}) \mathrm{cm}^{-1}$.

Dextran methylcarboxylate-iron oxide particle (4). Dextran methylcarboxylate (3) (0.50 g) and $\mathrm{FeCl}_{3} \cdot 6 \mathrm{H}_{2} \mathrm{O}(35 \mathrm{mg})$ were solved in $\mathrm{H}_{2} \mathrm{O}(4 \mathrm{~mL})$ and nitrogen was flushed for $1.5 \mathrm{~h}$. $\mathrm{FeCl}_{2} \cdot 4 \mathrm{H}_{2} \mathrm{O}(14 \mathrm{mg})$ was added, followed by aqueous ammonia $(100 \mu \mathrm{L})$ in two portions while the mixture was kept under nitrogen. The solution turned black and was heated to $80{ }^{\circ} \mathrm{C}$ for $100 \mathrm{~min}$. After the mixture was cooled to RT, the ammonia was removed by flushing the solution with nitrogen over $10 \mathrm{~min}$. Freeze drying led to the desired particles $4(0.55 \mathrm{mg})$, which are stable at $4{ }^{\circ} \mathrm{C}$ for at least one year and were used for all further experiments. Titration of the resulting particle $(18 \mathrm{mg})$ with $0.1 \mathrm{M} \mathrm{HCl}(0.85 \mathrm{~mL}, 85 \mu \mathrm{mol})$ and bromophenol blue in acetone $/ \mathrm{H}_{2} \mathrm{O}(1 / 1,10 \mathrm{~mL})$ resulted in $4.6 \mathrm{mmol} \mathrm{COO}^{-} \mathrm{g}^{-1}$. Size-distribution experiments were carried out as described above.

Electrostatic binding of peptide 1 to particle 4. Peptide $1(0.33 \mathrm{mg}, 0.23 \mu \mathrm{mol}, 1$ eq. $)$ and particle 4 (1.0 mg, $4.6 \mu \mathrm{mol} \mathrm{COO}^{-}, 20$ eq.) were dissolved in $\mathrm{H}_{2} \mathrm{O}(500 \mu \mathrm{L})$ and the solution was shaken for $12 \mathrm{~h}$ at RT. To purify the product an ultrafiltration device was used for centrifugation and after concentration the sample was washed with $\mathrm{H}_{2} \mathrm{O}(3 \times 2 \mathrm{~mL})$. Size-distribution experiments were carried out as described above. For fluorescence measurements the complex $(0.39 \mathrm{mg})$ was dissolved in $\mathrm{H}_{2} \mathrm{O}(200 \mu \mathrm{L})$ (solution L). Known amounts of this solution were placed in a cuvette containing $\mathrm{H}_{2} \mathrm{O}(500 \mu \mathrm{L})$ (Table 2). 
Table 2

\begin{tabular}{ccccc}
\hline $\begin{array}{l}\text { Amount of } \\
\text { solution } \mathrm{L} \text { in } \\
\text { cuvette }[\mu \mathrm{L}]\end{array}$ & $\begin{array}{l}\text { Fluorescence } \\
\text { (peak area) }\end{array}$ & $\begin{array}{l}\text { Calculated peptide } \\
\text { concentration in } \\
\text { cuvette }[\mu \mathrm{M}]\end{array}$ & $\begin{array}{l}\text { Average amount } \\
\text { of peptide in } \\
\text { solution } \mathrm{L}[\mu \mathrm{mol}]\end{array}$ & $\begin{array}{l}\text { Average ratio } \\
\text { peptide/amount of } \\
\text { carboxylic acid } \\
\text { groups }\end{array}$ \\
\hline 10 & 19100.5 & 11.78 & 0.12 & $1: 2.7$ \\
20 & 36670.4 & 22.62 & & 12.7 \\
\hline
\end{tabular}

Afterwards the sample was transferred in an ultrafiltration device again, and washed with $0.1 \mathrm{M} \mathrm{NaCl}(2 \mathrm{~mL})$ and $\mathrm{H}_{2} \mathrm{O}(2 \times 2 \mathrm{~mL})$. For fluorescence measurements the complex $(0.16 \mathrm{mg})$ was dissolved in $\mathrm{H}_{2} \mathrm{O}(200 \mu \mathrm{L})$. Known amounts of this solution were placed in a cuvette already containing $\mathrm{H}_{2} \mathrm{O}(1.2 \mathrm{~mL})$. No fluorescence was measured at any concentration.

Electrostatic binding of peptide 2 to particle 4. Peptide $2(0.47 \mathrm{mg}, 0.26 \mu \mathrm{mol}, 1 \mathrm{eq})$ and particle $4\left(0.67 \mathrm{mg}, 3.1 \mu \mathrm{mol} \mathrm{COO}^{-}, 12 \mathrm{eq}\right)$ were dissolved in $\mathrm{H}_{2} \mathrm{O}(1 \mathrm{~mL})$ and the solution was shaken for $12 \mathrm{~h}$ at RT. To purify the product an ultrafiltration device was used for centrifugation and after concentration the sample was washed with $\mathrm{H}_{2} \mathrm{O}(3 \times 2 \mathrm{~mL})$. For fluorescence measurements the complex $(1.1 \mathrm{mg})$ was solved in $\mathrm{H}_{2} \mathrm{O}(1.0 \mathrm{~mL})$ (solution $\left.\mathrm{M}\right)$. Definite amounts of this solution were placed in a cuvette already filled with $\mathrm{H}_{2} \mathrm{O}(1.2 \mathrm{~mL})$ (Table 3$)$.

Table 3

\begin{tabular}{ccclc}
\hline $\begin{array}{l}\text { Amount of } \\
\text { solution } \mathrm{M} \text { in } \\
\text { cuvette }[\mu \mathrm{L}]\end{array}$ & $\begin{array}{l}\text { Fluorescence } \\
\text { (peak area) }\end{array}$ & $\begin{array}{l}\text { Calculated peptide } \\
\text { concentration in } \\
\text { cuvette }[\mu \mathrm{M}]\end{array}$ & $\begin{array}{l}\text { Average amount of } \\
\text { peptide in solution } \\
\mathrm{M}[\mu \mathrm{mol}]\end{array}$ & $\begin{array}{l}\text { Average ratio } \\
\text { peptide/amount of } \\
\text { carboxylic acid } \\
\text { groups }\end{array}$ \\
\hline 10 & 5497.43 & 3.16 & & $1: 4.8$ \\
30 & 16915.2 & 9.24 & 0.38 & \\
40 & 21494.3 & 11.7 & & \\
\hline
\end{tabular}

In order to determine the peptide loading after washing the particle with $0.1 \mathrm{M} \mathrm{NaCl}$, peptide 2

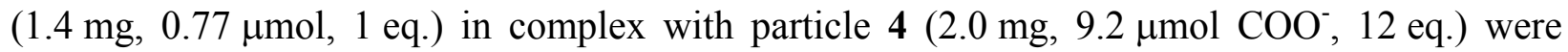
dissolved in $\mathrm{H}_{2} \mathrm{O}(1.5 \mathrm{~mL})$ and the solution was shaken for $12 \mathrm{~h}$ at RT. The sample was transferred into the ultrafiltration device and concentrated. Afterwards it was washed with $0.1 \mathrm{M}$ $\mathrm{NaCl}(3 \mathrm{~mL})$ and $\mathrm{H}_{2} \mathrm{O}(2 \times 3 \mathrm{~mL})$. For fluorescence measurements the complex $(1.0 \mathrm{mg})$ was dissolved in $\mathrm{H}_{2} \mathrm{O}(1.0 \mathrm{~mL})$ (solution $\left.\mathrm{N}\right)$. Known amounts of this solution were placed in a cuvette already containing $\mathrm{H}_{2} \mathrm{O}(1.2 \mathrm{~mL})$ (Table 4). 
Table 4

\begin{tabular}{ccccc}
\hline $\begin{array}{l}\text { Amount of } \\
\text { solution } \mathrm{N} \text { in } \\
\text { cuvette }[\mu \mathrm{L}]\end{array}$ & $\begin{array}{l}\text { Fluorescence } \\
\text { (peak area) }\end{array}$ & $\begin{array}{l}\text { Calculated peptide } \\
\text { concentration in } \\
\text { cuvette }[\mu \mathrm{M}]\end{array}$ & $\begin{array}{l}\text { Average amount } \\
\text { of peptide in } \\
\text { solution } \mathrm{N}[\mu \mathrm{mol}]\end{array}$ & $\begin{array}{l}\text { Average ratio } \\
\text { peptide/amount of } \\
\text { carboxylic acid } \\
\text { groups }\end{array}$ \\
\hline 20 & 7971.9 & 4.48 & & \\
30 & 11626 & 6.42 & 0.26 & $1: 9.8$ \\
40 & 14833 & 8.13 & & \\
60 & 21896 & 11.9 & & \\
\hline
\end{tabular}

\section{Acknowledgements}

This work was supported by the Deutsche Forschungsgemeinschaft (GRK 782). We are grateful for a fellowship from the Fonds der Chemischen Industrie for N. H.

\section{References and Footnotes}

1. Mahfouz, A.-E.; Hamm, B.; Taupitz, M. Eur. Radiol. 1997, 7, 507.

2. (a) Mazooz, G.; Mehlman, T.; Lai, T.-S.; Greenberg, C. S.; Dewhirst, M. W.; Neeman, M. Cancer Research 2005, 65, 4, 1369. (b) Leng, H.; Wang, X.; Niebur, G. L.; Roeder, R. K. Ceramic Transactions 2005, 159, 219.

3. Schmitz, S. A.; Winterhalter, S.; Schiffler, S.; Gust, R.; Wagner, S.; Kresse, M.; Coupland, S. E.; Semmler, W.; Wolf, K. J. Radiology 2001, 221, 237.

4. Schmitz, S. A.; Coupland, S. E.; Gust, R.; Winterhalter, S.; Wagner, S.; Kresse, M.; Semmler, W.; Wolf, K. J. Invest. Radiol. 2000, 35, 460.

5. Ferrucci, J. T.; Stark, D. D. Am. J. Roentgenology 1990, 155, 943.

6. (a) Hasegawa, M.; Hanaichi, T.; Shoji, H.; Kawaguchi, T.; Maruno, S. Jpn. J. Appl. Phys. 1998, 37, 1029. (b) Maruno, S. Patent USP 5204457.

7. Yancy, A. D.; Olzinski, A. R.; Hu, T. C-C.; Lenhard, S. C.; Aravindhan, K.; Gruver, S. M.; Jacobs, P. M.; Willette, R. N.; Jucker, B. M. J. Magn. Res. Imag. 2005, 21, 432.

8. Groman, E. V.; Paul, K. G.; Frigo, T. B.; Bengele, H.; Lewis, J. Patent WO 00/61191 A3, 2000.

9. (a) Li, W.; Tutton, S.; Vu, A. T.; Pierchala, L.; Li, B. S. Y.; Lewis, J. M.; Prasad, P. V.; Edelman, R. R. J. Magn. Res. Imag. 2005, 21, 46. (b) Jacobs, D. M.; Davis, R.; Shenouda, M.; Bolton, W. K. Am. J. Nephrol. 2005, 25, 4, 400.

10. Wunderbaldinger, P.; Josephson, L.; Weissleder, R. Bioconjugate Chem. 2002, 13, 264.

11. Kolonin, M.; Pasqualini, R.; Arap, W. Curr. Opinion Chem. Biol. 2001, 5, 308. 
12. Fukuda, M. N.; Ohyama, C.; Lowitz, K.; Matsuo, O.; Pasqualini, R.; Ruoslahti, E.; Fukuda, M. Cancer Research 2000, 60, 450.

13. Thierry, B.; Winnik, F. M.; Merhi, Y.; Tabrizian, M. J. Am. Chem. Soc. 2003, 125, 7494.

14. He, P.; Hu, N. J. Phys. Chem. B 2004, 108, 13144.

15. (a) Frank, J. A.; Miller, B. R.; Arbab, A. S.; Zywicke, H. A.; Jordan, E. K.; Lewis, B. K.; Bryant, L. H.; Bulte, J.W.M. Radiology 2003, 228, 480. (b) Arbab, A. S.; Bashaw, L. A.; Miller, B. R.; Jordan, E. K.; Lewis, B. K.; Kalish, H.; Frank, J. A. Radiology 2003, 229, 838.

16. Chan, W. C.; White, P. D. Eds. Fmoc Solid Phase Peptide Synthesis. A Practical Approach Oxford University Press, 2000.

17. Hayashida, O.; Hamachi, I. J. Org. Chem. 2004, 69, 3509.

18. Huynh, R.; Chaubet, F.; Jozefonvicz, J. Carbohydr. Res. 2001, 332, 75.

19. Kresse, M.; Pfefferer, D.; Lawaczek, R.; Wagner, S.; Ebert, W.; Elste, V.; Semmler, W.;

Taupitz, M.; Gaida, J.; Herrmann, A.; Juk1, M.; Swiderski, U. Patent DE 4428851 C2, 2000.

20. Signorell, R.; Kunzmann, M. K.; Suhm, M. A. Chem. Phys. Lett. 2000, 329, 52. 